\section{Every Student Can Be a Reader: A Balanced Literacy Program}

\section{Debbie Kilmer-Mesure}

W hat follows is a summary of a proposal to enhance the reading and writing skills of reluctant readers. It is called a Balanced Literacy Program. The acronym R.A.P., Reading Apprentice Program, captures the purpose and process of the program.

"When teachers, librarians and parents concentrate on plans to foster a love of reading in each child, communities become caring, literate places in which to live."

Charlotte Huck

"students who have been unsuccessful throughout elementary, middle and secondary school frequently adopt a negative stance towards reading that becomes more difficult to modify"

Mathewson, 1994 (Appendix A)

It is reasonable, therefore, to suggest that creative and explicit intervention for learning is a necessary curriculum skill required of all teachers. Pollack (1998) makes the point that mentor programs do work and, when boys meet on a regular basis with a buddy / coach as in the proposal I will outline below, boys demonstrate improved attitudes toward reading. They also develop positive self-esteem and other academic competencies.

The Ontario Ministry of Education Report "Me Read? No Way" suggests that every school should have a plan for helping boys to succeed in literacy skills. Whole literacy policies are needed to plan for the special needs of boy learners and reluctant readers. Strategies include inviting boys to select from a broad range of reading genres. Specifically, this means that teachers should target readers with material, which they want to read. Read with him, read to him and let him choose what he wants to read.

The key to unlocking the framework to cooperative and literate learners requires a rich backdrop that is committed to lifelong learning. Literacy is a powerful system, which demands the process of effective teaching practice while building on cultured reading experiences. Moreover, language and literacy learning demand observation of the common curriculum, flexibility of instruction and a common goal, which promotes the treasure of reading. This program provides opportunities for mentors to discuss reading and writing options and work together to find an appropriate leaning accommodation.

I believe that one must capture the potential of a struggling reader at an early age. As an alternative education teacher, it saddens me when I observe the potential in teenagers lost to frustration because they struggle with literacy skills. Many of these students (mostly boys) were identified as behavioural problems in their primary years and experienced failure and defeat in school. They often turned to alternative and often unconventional ways to communicate their inadequacies. After reading work by Patricia Paterson and Lori Elliot (1994/ 2006), I became intrigued by their project, "Struggling Reader to Struggling Reader: High school students' responses to a cross-age tutoring program". Because I am working toward my Reading Specialist Qualifications, I envisioned a program, which was similar but different, and one, which could be applied to a variety of settings. My experience with teenage boys, with their reluctance as readers and subsequent limited literacy skills, compelled me to try to design a program which could be adopted by the school at which I now teach.

The reading tutor program I have designed is based in kind on the underlying philosophy of the outreach Lauback Reading Program, "Teach One, Reach One" which is "we learn best by teaching someone else". The aim is to develop positive attitudes, increase reading skills and foster literacy enrichment by matching a "struggling reader to a struggling reader". However, unlike many buddy reader programs, this program matches elementary students, ages 7-12, with secondary students, ages 16-21, both of whom are struggling readers. The concept of "mirrored experiences" is a key component for "building relationships". According to Elliot and Patterson, "bringing students together with similar backgrounds and social circles" promotes the ability to bond quickly with one another. Matching struggling readers from junior school with struggling readers from a secondary school setting is seen as cross-age tutoring.

The R.A.P program is designed to address the needs of all participants. Thus, while promoting literacy in an enriched environment and encouraging partnerships between struggling readers and apprentices, R.A.P also accommodates the need to encourage academic and individual success. In consultation with the Ontario Ministry of Education, R.A.P. has received encouragement and support because participants will (pending final approval) receive one credit value for training and implementation over one semester under the Leadership and Peer Mentoring course or the GLD 
2040 course, Discovering and Navigating the Workplace, defined within the Ontario high school curriculum. A local Junior Public school is very interested in partnering in this project.

The Primary/Junior School Apprentice works within consultative guidelines and supervision of school administration, the special education resource teacher and a parent/guardian, where applicable.

\section{The apprentice:}

- provides the R.A.P. Teacher with a completed Reader Application Form. (Appendix sample B)

- provides the R.A. P. Teacher with the necessary information required which identifies the junior apprentice's special needs, learning modalities, preferences and interests.

- provides an "about me" information sheet or

- provides the R.A.P Teacher with a Letter of Introduction of himself or herself to the senior apprentice partner. This communication can be in written or artistic form, indicating his/her interests in a variety of genres.

- provides the R.A.P. Teacher with a written consent form to initiate the program in their preferred reading facility.

- maintains a journal of events from each R.A.P session.

\section{The Secondary School Apprentice}

- provides the R.A.P. Teacher with a completed Senior School Apprentice Participation form, (Appendix sample C).

- provides a volunteer police and vector-screening test.

- provides the R.A.P. Teacher with the necessary information required which identifies the Senior Apprentice's special needs, learning modalities, preferences and interests

- provides the R.A.P Teacher with a Letter of Introduction of himself or herself to the junior apprentice partner. This communication can be in written or artistic form, indicating his/her interests in a variety of genres.

- maintains a journal of events from each R.A.P session, which will contribute towards a portfolio for as culminating activity.

- provides the R.A.P. Teacher with a written consent form, which includes their classroom teacher endorsement. The credit courses, which may be offered in conjunction with this program, are the GLD10, Drama or LLL courses.

- earns a grade 9 English credit.

- agrees to fulfill the identified time commitment for hands on reading apprentice guidelines. (10 weeks accumulation)

- fulfills in-class literacy education training, strategic lesson planning and service delivery and apprentice expectations.

The R.A.P. teacher will prepare the apprentice by teaching what is meant by Guided and Shared Reading, Independent Reading, and a Read-aloud activities (etc). Strategies will be taught to prepare the senior reading apprentice for program implementation. An integration of "interest" content areas will be included. Differential instruction will also be encouraged for "self-direction and "intrinsic motivation". (Shaw, 2004: Appendix E).

\section{3) Explanation of Assessment:}

There are a variety of assessment tools to be considered for the implementation and evaluation of R.A.P. Assessment for this program will be ongoing for each student to ensure that targeted learning outcomes specific to his or her stage of educational development are met.
Some of these assessments may include:

- Initial informal pre- and postbaseline achievement testing of the junior and senior student apprentice.

- El Paso

- Tass

- Dolch Sight Word Test

- 44 primary sounds of the English language. (level 1 review: basic information, (Appendix E/uroregon.edu)

- Portfolio Assessment and Evaluation

Other forms of assessment may include:

- Consultation of junior testing with their SERT.

- R.A.P. Teacher summarizes one to one conferences with Senior R.A.P.

- Informal identification of learning modalities. (Appendix F)

- Maintenance of a "visual chart of observations" of junior apprentice success.

- User friendly junior and senior assessment of comprehension, conventions, interpretation, evaluations, synthesis, and context; assessment. (Appendix G)

- Ongoing observations of reading behaviours.

- QCharts

- Observation of the relationship between the two-paired apprentices. They must "mirror similar experiences" as a "key component for the relationship (which) creates a bond of community, experiences and social experiences." (Elliot \& Paterson, 2006)

- Journals and Portfolios (Appen$\operatorname{dix} \mathrm{H}$, sample guidelines)

Observational assessments include:

- Read Out Loud activities; picture walks; "Enhanced Learning Assessments"; observations, checklists, informal collaborative assessments, apprenticeship assessments, interest and self-esteem assessment/observation of the connection with the "love of reading model", (Elliot \& 
Paterson, 2006).

- Senior Apprentices prepare teacher directed lessons for R.A. P. sessions. They also prepare for read aloud, share conversa- tions with students and model good reading technique. Students will learn how reading out loud promotes literacy.

- Criteria based on approved in- formal assessments and evaluation based on the "Six Traits of an Effective Reader".

For example:

\begin{tabular}{|c|c|c|}
\hline $\begin{array}{l}\text { MONDAY } \\
\text { Home School }\end{array}$ & $\begin{array}{l}\text { READ ALOUD FOR } \\
\text { COMPREHENSION. } \\
\text { In class lesson. } \\
\text { Please note: teaching comprehension } \\
\text { is ongoing. This is only a sample. }\end{array}$ & $\begin{array}{l}\text { WHAT IS COMPREHENSION? } \\
\text { Utilize a Q chart for guiding } \\
\text { connections for comprehension. } \\
\text { (In chart form, Place helping verbs } \\
\text { diagonally; the } 5 \text { W's and how, ver } \\
\text { tically.) }\end{array}$ \\
\hline
\end{tabular}

\begin{tabular}{|l|l|}
\hline TUESDAY & $\begin{array}{l}\text { R.A.P. session in the Elementary School Library. } \\
\text { The Junior student selects a book of his/her } \\
\text { choice. }\end{array}$ \\
$\begin{array}{l}\text { Shared Reading } \\
\text { Environment and } \\
\text { apprenticeship } \\
\text { partnership time. Pre-conferences will take place. } \\
\text { 2. Read Aloud session. }\end{array}$ \\
$\begin{array}{l}\text { 3. Q chart will guide post conferences. } \\
\text { *Ask junior apprentice to select another book } \\
\text { from the library. The Senior student will borrow } \\
\text { it for next day's class and R.A.P. session. }\end{array}$
\end{tabular}

The laminated Q Chart will act as a tool to assist the Senior student to question for understanding. This provides opportunities for making predictions, understanding the main idea and opening the door for retell.

Journal and file any information for a portfolio.

\begin{tabular}{|l|l|l|}
\hline WEDNESDAY & $\begin{array}{l}\text { FOCUS ON COMPREHENSION } \\
\text { Journal time. (Reflect) }\end{array}$ & $\begin{array}{l}\text { Review the self- assessment for comprehen- } \\
\text { sion. } \\
\text { Practice read aloud strategies. }\end{array}$ \\
$\begin{array}{l}\text { Sharing of experiences. (Retell) } \\
\text { Next Steps. (Relate) } \\
\text { Practice reading the junior students book selection } \\
\text { and consider a dialogue for comprehension. }\end{array}$ & $\begin{array}{l}\text { Journal \& file any information for a } \\
\text { portfolio. }\end{array}$ \\
\hline
\end{tabular}

\section{THURSDAY}

Shared Reading

Environment and apprenticeship partnership time.
R.A.P.

Sharing time and dialogue of previous book, (for observation of long-term memory/likes and dislikes). Read aloud to student.

Shard reading activity of the same book. Complete the comprehension chart with the junior student.
Reflect on the comprehension chart with partnered reading apprentice. Select a new book for the next R.A.P. session. Senior student shall borrow this text and prepare for next week's R.A.P. session. Prepare for a lesson of conventions for next week. See appendix G Journal \& file any information for a portfolio.

\section{REFERENCES}

Booth, David. (2002) Even Hockey Players read: Literacy and Learning. Markham, On: Pembrooke

Child1st Publications, (2007) Reading Made Easy.

Sebastian, Florida. retrieved from http:/ /www.child-1st.com/index.html

Dolch, E.W. (2002/2006) Assessment Tool. retrieved from http:// literacyconnections.com/Dolch.php

Ekwall, E.E. \& Shanker, J. L. (1999) EL Paso phonics Survey: Found in: Ekwall/Shanker Reading Inventory, Fourth Edition. Allyn \& Bacon, Inc.
Flesh, R. (1995) Why Johnny Can't read. New York: Harper and Row

Huck, Charlotte (2006) retrieved from http:// www.ed.gov/programs/ nclbbrs/2006/applications/tx04donald-elementary.pdf

Ontario Ministry of Education. (2004) Me Read? No Way! A practical guide to improving boys' literacy skills.

Paterson, P., Elliot, L.N., Paterson (2006). Struggling reader to struggling reader: a cross-age tutoring program. Journal of Adolescent Adult Literature: International Reading Association. Feb. (V.49) \# 5 ISSN 1081-3004
Mathewson, G. C. (1994) Model of attitude influence upon reading and learning to read. In R.B.Buddel, Ruddel, M.R. and Singer, H. (EDS) Theoretical models and processes of reading ( $4^{\text {th }}$ ed. Pp 11311162). Newark ED: International Reading Association.

Pollack, William S. (1998) Real Boys: Rescuing our boys from the myths of boyhood. New York: Henry Holt

Rosner, Jerome M.D. (1993) Test of Auditory Analysis Skills-TASS.

Rosner, Jerome M.D. (1992/2007) Helping Children Overcome Learning Difficulties. New York: Walker Publishing Company 
4:1 Spring 2007

Scieszka, Jon (2003) Guys and Reading. Teacher Librarian, 30(3), 17-18

SEDL: Southwest Educational Development Laboratory (2007) Reading Assessment DataBase, retrieved from: http://www.sedl.org/reading/rad/ database.html

Taylor, Deborah and Lorimer, Maureen (2002/2003). Helping boys succeed. Educational leadership, 60(4), 68-70

Trelease, Jim.(1992). Hey Listen to this: Stories to Read Aloud. Penguin Books New York

Authors Note:

What makes this program unique is that RAP' goal is to instruct all senior apprenticesin the methodology and delivery skills of the Association Method Part 1; University of Southern Mississippi; Dubard School for Language Disorders course. This instruction includes the 44 primary and 27 secondary sounds of the English language.

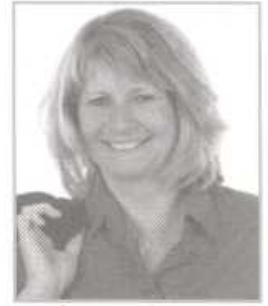

Deborah A. KilmerMesure, B.A. B.Ed. Debbie graduated from the University of Guelph Ontario, in 1979. She majored in English and Drama. During her undergraduate career at Guelph University, she was a practicum instructor for the Department of Human Kinetics. From 1980 to 1995, Debbie was an occasional and substitute teacher with the Halton District School Board. During this tenure, she taught grades seven to twelve, alternative and adult education. Concurrently, she continued to upgrade her University Degree at the University of Guelph.

In 1995, Debbie embarked on her fulltime career in education and attended Brock University Faculty of Education; Intermediate and Senior Panels. Between the years 2002-2006, she earned her Specialist in Special Education,
(Learning Disabilities), and Reading Parts $1 \& 2$. Additionally, she completed the summer course on the Association Method for Teaching Literacy Skills to Children, offered through William L. McMaster \& Associates Incorporated. Currently, she is pursuing her Junior Basic Curriculum and Instruction Qualifications.

Since 1996, Debbie provided instruction in grades 7- 11 for the Halton Board of Education. Subsequent to this, she was secondonded to the Ministry of Education Demonstration School in Milton, Ontario. Today, Debbie instructs 16-21 year-olds at The Centre for Individual Studies for the Kawartha Pine Ridge District School Board. She is a member of the KPRDSB Literacy Program Council, (POR), and the OSSLC, Moderated Marking Team.

Through her professional experiences she has observed the need for diverse programming and teaching strategies for struggling and dis-engaged students.

\section{Boys Don't Read - It's True!}

\section{David Skuy}

$\mathrm{F}$ ew educational experts would disagree that school-aged boys are falling behind their female counterparts in terms of reading and writing, a gap that both increases with grade levels, and has increased in recent years. Recent studies suggest this trend is not isolated to one geographic region or demographic group. It is all boys across North America and Europe. As a father of a seven-year old son, I worry about my son reading as he gets older. As an author of a Young Adult book series for boys, I worry if there is a market for my books. By the time high school hits over half of all boys describe themselves as non-readers. To make matters worse, the publishing industry has figured this out - and 'Boy Books' have disappeared from the shelves (apart from Harry Potter and its legions of copycats). The economic impact of poor literacy skills for half the population is self-evident. The spiritual impact of a child deprived of one of the great pleasures in life is less obvious, but perhaps even more detrimental to society.

As a young boy I grew up reading sports stories and playing hockey. So what better subject matter for my first foray into the children's lit genre? "Good luck trying to sell the idea let alone the manuscript," a publisher once told me told me. "Boys don't read."

Boys don't read? That was the first I'd heard of it. My daughter loved reading and I just assumed my young son would also. I be- gan to research the subject - and sure enough, I found out my publisher friend was absolutely right. It seems that once boys hit eight or nine years old, they lose interest and stop reading.

In Canada, the Ontario government recently conducted an extensive study of literacy levels. In 2004, it produced a study - Literacy for Learning - The Report of the Expert Panel on Literacy in Grades 4 to 6 in Ontario. The report shows that boys are dropping out of arts courses as soon as they can. In testing of primary school children, girls consistently outperform boys in reading and writing tests by a wide margin. This is consistent with international results. The same findings were reached in a recent study of 36 countries (see Newsweek Magazine, January 30, 2006). Business leaders are beginning to take notice, complaining that recent university graduates often lack basic literacy skills. 